Jacobo Danke

\title{
Una muchacha ha entrado en la ciudad...
}

Amigo Ciprés, Agua Confidente, Golondrina del hábito negro, ved cuánta luz de día desciende de la urna sobre esta otra urna que conduce la cabellera sombria de una muchacha Y su sonrisa de hielo $\mathrm{y}$ sus pobres zapatos fatigados. ¿Cuánto derroche del reino de los ámbitos, para que una manzana en sazón venga a marchitarse entre los pinos y el mármol de rostro duro! ¿No la veis acodada en la borda de un navio mientras los labios del viento cantan en las cuerdas? ¿O colocándose en el pecho una flor apasionada? ¿O jugando a la novia con un azahar de nieve? Yo si la veo. 
Piedra, Cineraria, Bronce, Cristal, Incienso: Vuestros semblantes en la luz reconocidos no son ya una parábola de muerte sino ese murmullo con que el trigo alza la espiga donde la cal recluta nuevas horas, nuevos minutos para lo engañoso del miraje con que vendrá deshojándose el futuro. Saboreo los signos de dulce inteligencia que os hacéis con vuestra huésped silenciosa: La piedra, con la gota de sangre de su anillo; la Cineraria, con el pliegue doliente de su falda; el Bronce, con la hebilla de su cinturón ajado; el Cristal, con el ritmo a la sordina de su voz; el Incienso, con el perfume de sus lejanos sueños.

Pudo llamarse Paloma por la profundidad malva que su paso despertó en las tardes rubias, - Florencia, como la ciudad de atormentadas torres que mi sombra desgastó de recorrerla a través de los rios nocturnos del insomnio. [Qué importa a vuestros alborozos mudos! Aquí tendrá también un ruiseñor demente para su dedo, bajo la pompa matinal;

y una abeja enamorada de su boca;

Y zarcillos de música ideal para el oido

Y para sus pupilas vestidas por la bruma eterna, paisajes con un fondo de frutas y de tórtolas. 
https://doi.org/10.29393/At369-475JDME10475

Una muchacha

215

Brillo, cadencia, destinos de una misma ola. Y la muchacha con un sol agónico en la mano, ¿no es la criatura que ha de volver trocada en polen, en mariposa de seda, en almendros delirantes?

Abridle camino, pues, entre vuestras cúpulas, entre la galeria de arpegios de los mausoleos, como a una niña ciega en medio de la noche. $\mathrm{Su}$ pie desenhebra el eco de los dormidos siglos $y$ todos aquellos que la precedieron tienden la palma, le ofrecen el vaivén dorado de su corazón. 